\title{
Isolation and Physiological Characterization of Mitomycin C-sensitive/ UV-sensitive Mutants in Bacteroides fragilis
}

\author{
By VALERIE R. ABRATT, DAVID T. JONES AND \\ DAVID R. WOODS* \\ CSIR Microbial Genetics Research Unit, Department of Microbiology, University of Cape Town, \\ Rondebosch 7700, South Africa
}

(Received 23 October 1984; revised 25 March 1985)

\begin{abstract}
Mutants of Bacteroides fragilis sensitive to mitomycin $\mathrm{C}$ were isolated after mutagenesis with ethyl methane sulphonate. One mutant (MTC25) was markedly sensitive to mitomycin C but was unaffected as regards UV sensitivity; another mutant (UVS9) was sensitive to UV radiation but was only moderately sensitive to mitomycin $\mathrm{C}$. Caffeine decreased the survival after UVirradiation of the wild-type, MTC25 and UVS9 strains by the same relative amount. Aerobic liquid holding recovery occurred in each of the three strains. The MTC25 and UVS9 mutants showed reduced host cell phage reactivation. The wild-type, MTC25 and UVS9 strains all showed UV- and $\mathrm{H}_{2} \mathrm{O}_{2}$-induced phage reactivation. The physiological characterization of the MTC25 and UVS9 mutants indicates that it is possible to differentiate between mechanisms for the repair of mitomycin C- and UV-induced DNA damage in $B$. fragilis.
\end{abstract}

\section{INTRODUCTION}

Although DNA repair mechanisms have been extensively studied in Escherichia coli and other aerobic bacteria, the DNA repair systems of obligate anaerobes have been largely neglected. The anaerobe Bacteroides fragilis is interesting in that survival after irradiation with far-UV light is affected by oxygen (Jones et al., 1980; Slade et al., 1981). Furthermore, novel $\mathrm{O}_{2}$ - and $\mathrm{H}_{2} \mathrm{O}_{2}$-induced phage reactivation systems have been reported for $B$. fragilis (Slade et al., 1983a, $b$ ). Since UV-sensitive mutants have played a major role in the elucidation of DNA repair mechanisms in $E$. coli we attempted the isolation of UV-sensitive mutants of $B$. fragilis.

Mutants of $B$. fragilis and other obligate anaerobes are difficult to obtain (Sebald \& Costilow, 1975; Van Tassel \& Wilkins, 1978; Droffner \& Yamamoto, 1983); indeed, Droffner \& Yamamoto (1983) reported the inhibition of mutagenesis in Salmonella typhimurium by anaerobic conditions. Since a correlation between UV sensitivity and mitomycin C sensitivity has been reported in E. coli (Boyce \& Howard-Flanders, 1964), Micrococcus radiodurans (Moseley, 1967), Bacillus subtilis (Okubo \& Romig, 1966) and S. typhimurium (Ames et al., 1973), an indirect selection procedure utilizing mitomycin $C$ was investigated. Mitomycin $C$ has been reported to be chemically activated by reduction with hydrogen in the presence of a palladium catalyst, but it is highly unstable in this form and rapidly loses its DNA crosslinking ability (Szybalski \& Iyer, 1967). Its suitability as a selective agent under anaerobic conditions had to be established.

\section{METHODS}

Bacteria and phages. These studies were done with a $B$. fragilis strain $(\mathrm{Bf}-2)$ and the phage $\mathrm{b}-1$ which have been used in previous studies on far-UV irradiation effects (Jones et al., 1980; Jones \& Woods, 1981).

Media. Brain heart infusion broth and agar supplemented with haemin, menadione and cysteine (Holderman \& Moore, 1972) were used for bacterial growth at $37^{\circ} \mathrm{C}$. Anaerobic one-quarter-strength Ringer's solution was used as a dilution buffer. All anaerobic manipulations were done under stringent anaerobic conditions in an anaerobic glove cabinet (Forma Scientific, Marietta, Ohio, USA) in an atmosphere of $75 \% \mathrm{~N}_{2}, 20 \% \mathrm{CO}_{2}$ and $5 \% \mathrm{H}_{2}$. 
Mutagenesis and isolation of mutants. Ethyl methane sulphonate $(2 \%, \mathrm{v} / \mathrm{v})$ was added to exponential phase $B$. fragilis cells $\left(\mathrm{OD}_{6,00} 0 \cdot 3\right)$ and the culture was incubated for $25 \mathrm{~min}$ at $37^{\circ} \mathrm{C}$ (approximately $10 \%$ survival). The cells were sedimented by centrifugation, resuspended in fresh brain heart infusion broth and incubated for $20 \mathrm{~h}$. The culture was diluted and plated to give approximately $100 \mathrm{c.f}$.u. per plate. After $18-20 \mathrm{~h}$ incubation the pin-pricksized colonies were replica plated onto agar plates containing mitomycin $C\left(0 \cdot 1 \mu \mathrm{g} \mathrm{ml}^{-1}\right)$ and control plates without mitomycin $\mathrm{C}$. Colonies which did not grow on the mitomycin $\mathrm{C}$ plates were retested for mitomycin $\mathrm{C}$ and UV sensitivity.

UV irradiation experiments. Methods for measuring survival after UV irradiation, liquid holding recovery, uninduced and $\mathrm{UV}$ - or $\mathrm{H}_{2} \mathrm{O}_{2}$-induced reactivations of phage b-1 were as described by Jones \& Woods (1981), Slade et al. (1983a,b) and Schumann et al. (1984).

\section{RESULTS}

\section{Activity of mitomycin $C$ under anaerobic conditions}

The suitability of an indirect selection procedure for UV sensitivity based on the use of mitomycin $\mathrm{C}$ was investigated, as mitomycin $\mathrm{C}$ has been shown to be chemically activated to an unstable form under reducing conditions (Szybalski \& Iyer, 1967). The MIC for B. fragilis Bf-2 cells $\left(100\right.$ c.f.u. $\left.\mathrm{ml}^{-1}\right)$ plated on freshly poured plates placed immediately under anaerobic conditions, or plates stored aerobically for $24 \mathrm{~h}$ before exposure to anaerobic conditions in the anaerobic cabinet, was $0 \cdot 14 \mu \mathrm{g}$ mitomycin $\mathrm{C} \mathrm{ml}^{-1}$. If plates containing mitomycin $\mathrm{C}$ were kept in anaerobic conditions for $24 \mathrm{~h}$ the compound lost activity and the MIC was greater than $7 \mu \mathrm{g}$ mitomycin $\mathrm{C} \mathrm{ml}^{-1}$.

\section{Isolation of mitomycin $C$ - and $U V$-sensitive mutants}

After ethyl methane sulphonate mutagenesis, six mutants were identified as being sensitive to mitomycin C. Five of these showed similar sensitivity to mitomycin C (MIC $0.06 \mu \mathrm{g} \mathrm{ml}^{-1}$ ) and all showed wild-type resistance to UV. These strains may have been siblings and one of them (MTC25) was chosen for further study. Growth of the sixth mitomycin C-sensitive mutant was inhibited by $0.08 \mu \mathrm{g}$ mitomycin $\mathrm{C} \mathrm{ml}^{-1}$, a concentration intermediate between that which inhibited the MTC25 and wild-type strains. This mutant designated UVS9, showed increased sensitivity to UV radiation. Representative survival curves showing sensitivity to mitomycin C and UV radiation are shown in Figs 1 and 2. The mean UV radiation lethal dose (Harm, 1980) for the wild-type and MTC25 strains was $15 \mathrm{~J} \mathrm{~m}^{-2}$ (Table 1), and the relative sensitivity of the UVS9 mutant was $1 \cdot 5$-fold.

\section{Effect of caffeine on survival after UV irradiation}

The MIC of caffeine for the wild-type, MTC25 and UVS9 strains was $2.5 \mathrm{mg} \mathrm{ml}^{-1}$. When these three strains were irradiated and plated on brain heart infusion agar containing $1 \mathrm{mg}$ caffeine $\mathrm{ml}^{-1}$, a marked decrease in survival was observed compared with the survival on the control plates (Fig. 2). The dose reduction factor (Harm, 1980) at $1 \%$ survival was 0.7 for each of the three strains.

\section{Liquid holding recovery}

The survival of irradiated stationary phase wild-type, MTC 25 and UVS9 cells was enhanced after holding in aerobic one-quarter-strength Ringer's solution (Table 1). Unirradiated cells held in the aerobic Ringer's solution showed no change in survival. Irradiated wild-type and MTC25 strains held under anaerobic conditions showed a decrease in survival whereas the UVS9 strain showed a small increase in survival. Unirradiated cells held anaerobically showed no change. Jones \& Woods (1981) reported that exponential phase cells showed higher liquid holding recovery levels than stationary phase cells and similar results were obtained with the wild-type, MTC25 and UVS9 strains. 


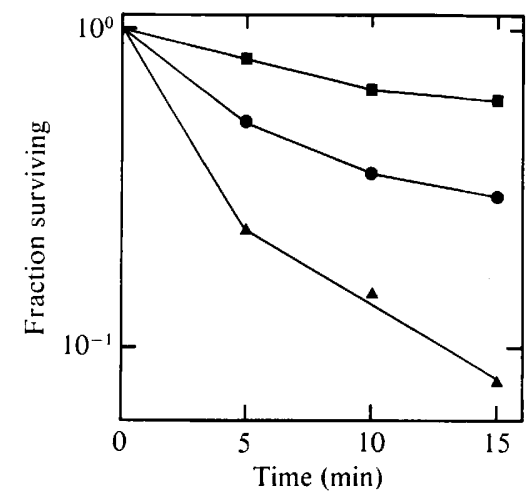

Fig. 1

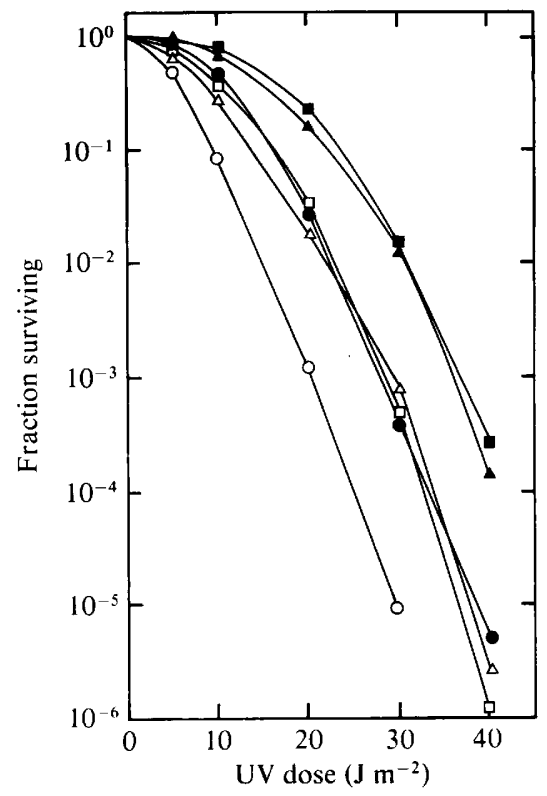

Fig. 2

Fig. 1. Effect of mitomycin $C$ on the survival of $B$. fragilis strains. Stationary phase cultures were diluted $10^{-3}$ into anaerobic one-quarter-strength Ringer's solution containing $20 \mu \mathrm{g}$ mitomycin C $\mathrm{ml}^{-1}$ and the number of c.f.u. determined. $\mathbf{\square}$, Wild-type strain; $\boldsymbol{\Delta}$, strain MTC25; strain UVS9.

Fig. 2. Effect of caffeine on the survival of UV-irradiated $B$. fragilis strains. Cells were irradiated with increasing doses of UV radiation $(254 \mathrm{~nm})$ and plated on brain heart infusion agar with and without $1 \mathrm{mg}$ caffeine $\mathrm{ml}^{-1}$. Wild-type strain plated with $(\square)$ and without $(\square)$ caffeine; strain MTC25 with $(\triangle)$ and without $(\Delta)$ caffeine; strain UVS9 with $(O)$ and without $(\mathbf{O})$ caffeine.

Table 1. Repair phenotypes of wild-type B. fragilis and mutant strains

$\begin{array}{lcccc}\text { Strain } & { }^{*} \mathrm{~F}_{0.37} & \begin{array}{c}\text { Mitomycin C } \\ \text { MIC } \\ \left(\mu \mathrm{g} \mathrm{ml}^{-1}\right)\end{array} & \overbrace{\text { Aerobic }} & \text { Anaerobic } \\ \text { Wild-type } & 15 & 0.14 & 2.1 & 0.45 \\ \text { MTC25 } & 15 & 0.06 & 1.8 & 0.48 \\ \text { UVS9 } & 10 & 0.08 & 2.3 & 1.6\end{array}$

* Mean lethal dose (dose resulting in $37 \%$ survival of cells).

$\dagger$ Liquid holding recovery. Cells were irradiated to $1 \%$ survival and held at $30{ }^{\circ} \mathrm{C}$ for $2 \mathrm{~h}$ in minimal salts solution (anaerobic) or one-quarter-strength Ringer's solution (aerobic). Results are expressed relative to irradiated cells plated immediately. Data from one of five independent experiments are given. The results from all the experiments were within $\pm 9 \%$ of the values given.

\section{Phage reactivation}

Slade et al. $(1983 a, b)$ investigated the optimum conditions for $\mathrm{UV}$ - and $\mathrm{H}_{2} \mathrm{O}_{2}$-induced phage reactivation in $B$. fragilis $\mathrm{Bf}-2$. Similar experiments with the mutants MTC25 and UVS9 indicated that the optimum conditions of UV-irradiation and $\mathrm{H}_{2} \mathrm{O}_{2}$ concentration for phage reactivation were the same as for the wild-type. The efficiency of plating of the unirradiated phage on the wild-type, MTC25 and UVS9 strains was identical. The MTC25 and UVS9 mutants both showed a decrease in uninduced host cell phage reactivation and UV-induced phage reactivation relative to the wild-type (Table 2). The UVS9 mutant differed from the wildtype and MTC25 strains in that it showed a reduction in $\mathrm{H}_{2} \mathrm{O}_{2}$-induced phage reactivation to about $33 \%$ of that seen in these strains. 


\section{Table 2. Bacteriophage reactivation}

Phage b-1 was UV-irradiated $\left(300 \mathrm{~J} \mathrm{~m}^{-2}\right.$ ), and the extent of uninduced host cell reactivation and UVand $\mathrm{H}_{2} \mathrm{O}$,-induced host cell reactivation were determined as described previously (Slade $e t$ al., $1983 a, b)$.

$\begin{array}{llll}\text { Uninduced* } & \overbrace{\mathrm{H}_{2} \mathrm{O}_{2}}^{\text {Induced }} \\ \text { Strain } & 1 & 6 \cdot 3( \pm 2 \cdot 8) & \mathrm{UV} \\ \text { Wild-type } & 0 \cdot 22( \pm 0 \cdot 14) & 6 \cdot 7( \pm 2 \cdot 4) & 2 \cdot 6( \pm 0 \cdot 7) \\ \text { MTC25 } & 0 \cdot 25( \pm 0 \cdot 11) & 2 \cdot 2( \pm 1 \cdot 9) & 3.5( \pm 0 \cdot 6)\end{array}$

${ }^{*}$ Relative to the wild type expressed as 1 . The mean of eight experiments is shown, \pm the range.

$\uparrow$ Relative to the uninduced level of that strain expressed as 1 . The mean of six and four experiments is shown for $\mathrm{H}_{2} \mathrm{O}_{2}$ and $\mathrm{UV}$, respectively, \pm the range.

\section{DISCUSSION}

Although the activity of mitomycin $\mathrm{C}$ has been reported to be affected by anaerobic conditions (Szybalski \& Iyer, 1967) it was successfully used for the isolation of two different mitomycin $\mathrm{C}$-sensitive $\boldsymbol{B}$. fragilis mutants by the use of controlled experimental conditions. The MTC25 mutant is markedly sensitive to mitomycin $C$ but is unaffected as regards UV sensitivity. The UVS9 mutant is sensitive to UV but is only moderately sensitive to mitomycin C. A similar correlation between the repair of mitomycin C-and UV-induced lesions has been observed in $M$. radiodurans (Moseley \& Copeland, 1978). In M. radiodurans it has been shown that two separate DNA excision repair pathways exist, one requiring a functional $m t c A$ gene and the other functional $u v s C, u v s D$ and $u v s E$ genes, and that mutational blocks in both must exist for an excisionless phenotype to be expressed (Evans \& Moseley, 1983; Moseley \& Evans, 1983).

The $B$. fragilis UVS9 mutant showed a dose reduction factor (Harm, 1980) of 0.6 at $1 \%$ survival compared to the wild-type. The main difference between the UV survival curves of the wild-type and UVS9 strains was in the shoulder region where repair of the DNA damage occurs at low UV doses.

In $E$. coli, liquid holding recovery is observed in cells having functional uvr and polA gene products, but only if they have some other decreased repair capacity as is found in $E$. coli $\mathrm{B}$ or E. coli K12 recA mutants (Ganesan \& Smith, 1968, 1969). In $B$. fragilis, aerobic liquid holding recovery occurs in the wild-type as well as in both mutant strains. Under anaerobic conditions, where the wild-type is functioning optimally, a negative liquid holding effect was observed. This is a phenomenon usually found in cells which are repair proficient and where holding is detrimental to recovery (Harm, 1980). The MTC25 mutant also showed a negative liquid holding effect, which is in agreement with the wild-type level of UV resistance found in this strain. The UV-sensitive UVS9 strains however, showed a tendency towards recovery on holding under anaerobic conditions, which correlates with its UV-sensitive phenotype. Jones \& Woods (1981) reported the inhibition of liquid holding recovery under anaerobic conditions but did not observe the negative liquid holding effect.

$\mathrm{H}_{2} \mathrm{O}_{2}$-induced phage reactivation revealed a further difference between the two $B$. fragilis mutant strains. Phage reactivation in the MTC25 mutant was induced to the same extent as in the wild-type by $\mathrm{H}_{2} \mathrm{O}_{2}$, but the UVS9 mutant showed reduced $\mathrm{H}_{2} \mathrm{O}_{2}$-induced reactivation.

The isolation and physiological characterization of the mitomycin C-sensitive and UVsensitive mutants in $B$. fragilis, which is difficult to mutate, is an important and essential requirement for future studies on repair pathways in this important obligate anaerobe.

\footnotetext{
Valerie R. Abratt acknowledges postgraduate research bursaries from the South African Council for Scientific
} and Industrial Research and from the University of Cape Town. 


\section{REFERENCES}

Ames, B. N., Lee, F. D. \& Durstan, W. C. (1973). An improved bacterial test system for the detection and classification of mutagens and carcinogens. Proceedings of the National Academy of Sciences of the United States of America 70, 782-786.

Boyce, R. P. \& Howard-Flanders, P. (1964). Genetic control of DNA breakdown and repair in $E$. coli $\mathrm{K} 12$ treated with mitomycin $\mathrm{C}$ or ultraviolet light. Zeitschrift für Vererbungslehre 95, 345-350.

DroffNer, M. L. \& Yamamoto, N. (1983). Anaerobic cultures of Salmonella typhimurium do not exhibit inducible proteolytic function of the $\operatorname{rec} A$ gene and rec $B C$ function. Journal of Bacteriology 156, 962-965.

Evans, D. M. \& Moseley, B. E. B. (1983). Roles of the $u v s C$, uvs $D$, uvsE and $m t c A$ genes in the two pyrimidine dimer excision repair pathways of Deinococcus radiodurans. Journal of Bacteriology 156, 576-583.

Ganesan, A. K. \& SMith, K. C. (1968). Dark recovery processes in E. coli irradiated with UV light. I. Effect of $\mathrm{rec}^{-}$mutants on liquid holding recovery. Journal of Bacteriology 96, 365-373.

Ganesan, A. K. \& Smith, K. C. (1969). Dark recovery processes in $E$. coli irradiated with UV light. II. Effects of uvr genes on liquid holding recovery. Journal of Bacteriology 97, 1129-1133.

HARM, W. (1980). Biological Effects of Ultraviolet Radiation. Cambridge: Cambridge University Press.

Holderman, L. V. \& MOORE, W. E. C. (editors) (1972). Anaerobe Laboratory Manual, 4th edn. Blacksburg, Va.: Virginia Polytechnic Institute and State University Anaerobe Laboratory.

JoNES, D. T. \& WoODS, D. R. (1981). Effect of oxygen on liquid holding recovery of Bacteroides fragilis. Journal of Bacteriology 145, 1-7.

Jones, D. T., RoBb, F. T. \& Woods, D. R. (1980). Effect of oxygen on $B$. fragilis survival after UV irradiation. Journal of Bacteriology 144, 11791181 .

Moseley, B. E. B. (1967). The isolation and some properties of radiation-sensitive mutants of Micrococcus radiodurans. Journal of General Microbiology 49, 293-300.

Moseley, B. E. B. \& Copeland, H. J. R. (1978). Four mutants of Micrococcus radiodurans defective in the ability to repair DNA damaged by mitomycin C, two of which have wild type resistance to ultraviolet radiation. Molecular and General Genetics 160, 331337.

Moseley, B. E. B. \& Evans, D. M. (1983). Isolation and properties of strains of Micrococcus (Deinococcus) radiodurans unable to excise ultraviolet lightinduced pyrimidine dimers from DNA : evidence for two excision pathways. Journal of General Microbiology 129, 2437-2445.

OKuBo, S. \& Romig, W. R. (1966). Impaired transformability of $B$. subtilis mutant sensitive to mitomycin $C$ and ultraviolet radiation. Journal of Molecular Biology 15, 440-454.

Schumann, J, P., Jones, D. T. \& Woods, D. R. (1984). Effect of UV irradiation on macromolecular synthesis and colony formation in B. fragilis. Journal of General Microbiology 130, 771-777.

Sebald, M. \& Costilow, R. N. (1975). Minimal growth requirements for Clostridium perfingens and isolation of auxotrophic mutants. Applied Microbiology 29, 1-6.

Slade, H. J. K., Jones, D. T. \& Woods, D. R. (1981). Effect of oxygen radicals and peroxide on survival after U.V. irradiation and liquid holding recovery of Bacteroides fragilis. Journal of Bacteriology 147, 685687.

Slade, H. J. K., Schumann, J. P., Jones, D. T. \& Woods, D. R. (1983a). Peroxide inducible phage reactivation in $B$. fragilis. FEMS Microbiology Letters 20, 401-405.

Slade, H. J. K., Schumann, J. P. S., Parker, J. R., JoNES, D. T. \& Woods, D. R. (1983b). Effect of oxygen on host cell reactivation in B. fragilis. Journal of Bacteriology 153, 1545-1547.

SZYBALSKI, W. \& IYER, V. N. (1967). The mitomycins and porfiromycins. In Antibiotics I: Mechanisms of Action, pp. 211-245. Edited by D. Gottlieb \& P. D. Shaw. Berlin, Heidelberg \& New York: SpringerVerlag.

VAN TASSEL, R. L. \& Wilkins, T. D. (1978). Isolation of auxotrophs of $B$. fragilis. Canadian Journal of Microbiology 24, 1619-1621. 